\title{
Cryptococcal meningoencephalitis and pulmonary nodule in a non-HIV-infected immunocompetent patient
}

Meningoencefalite criptocócica e nódulo pulmonar em paciente HIV negativo e imunocompetente

José Roberto Lambertucci ${ }^{1}$, Ricardo Franco ${ }^{1}$ and Leonardo Campos de Queiroz ${ }^{2}$

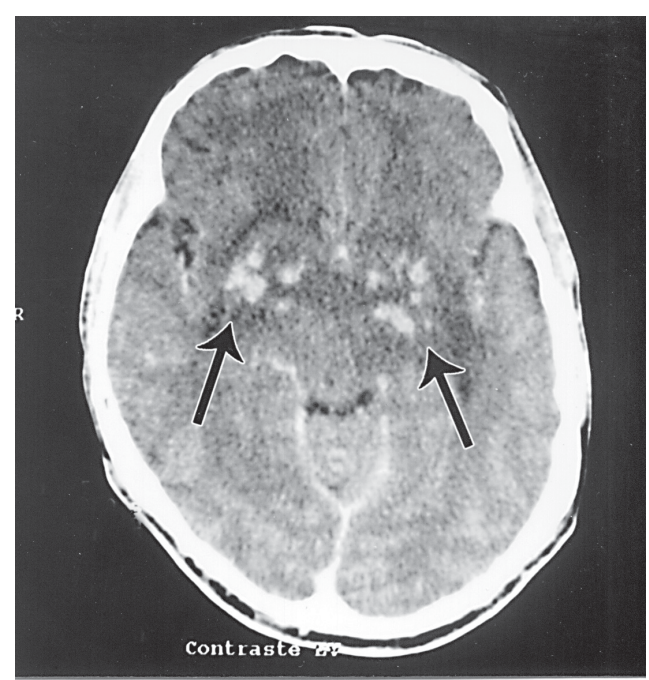

A

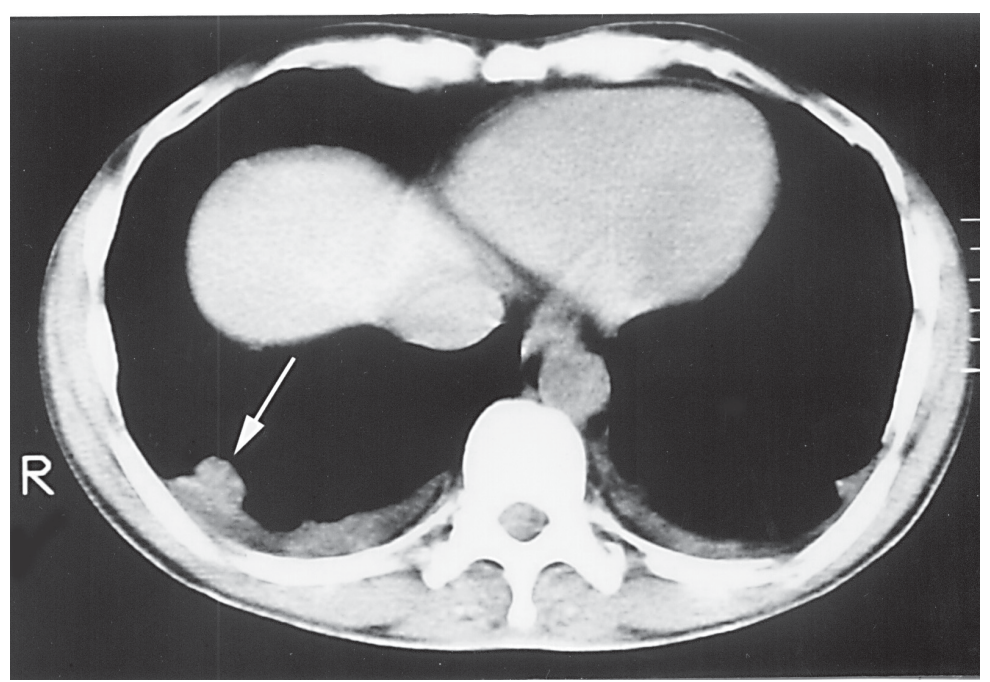

B

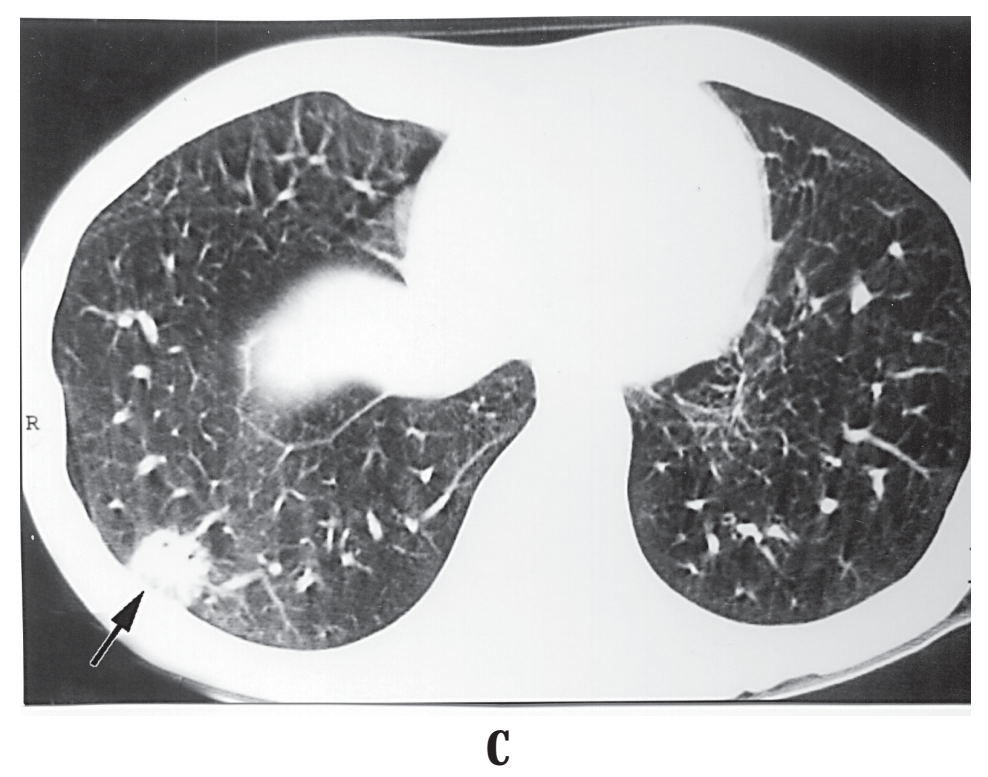

1. Serviço de Doenças Infecciosas e Parasitárias da Faculdade de Medicina da Universidade Federal de Minas Gerais, Belo Horizonte, MG. 2. Serviço de Radiologia da Faculdade de Medicina da Universidade Federal de Minas Gerais, Belo Horizonte, MG.

Address to: Prof. José Roberto Lambertucci. FM/UFMG. Av. Alfredo Balena 190, 30130-100 Belo Horizonte, MG.

e-mail: lamber@uai.com.br

Recebido para publicação em 2/2/2005

Aceito em 5/2/2005 
A 39-year old man was admitted to hospital with a history of fever, headache, nausea, photophobia and vomiting which started six days earlier. A lumbar puncture confirmed the diagnosis of meningitis caused by the fungus Cryptococcus neoformans. ELISA, western blot and PCR for HIV infection resulted negative. Clinical history and a series of tests excluded subjacent immunodeficiency and other associated diseases. Computed tomography (CT) of the brain depicted the presence of multiple nodules in the basal ganglia with contrast enhancement ( Figure A - arrows). He was treated with conventional amphotericin B ( $50 \mathrm{mg} /$ day) and improved quickly. CT of the lungs revealed bilateral pleural effusion and a slightly irregular solitary nodule in the periphery of the right lower lobe (Figure B - arrow). Ten days after starting amphotericin $B$, renal insufficiency, phlebitis, sepsis and disturbances in fluid and electrolytes balance were observed and fluconazole was substituted for amphotericin B. The patient was discharged from hospital 25 days later in good clinical condition. After a stay at home for twenty days he returned to hospital with symptoms resembling those of the firstadmission. A lumbar tap confirmed the diagnosis of meningitis: cryptococcal antigen was found in the cerebral spinal fluid (1:32). Intravenous liposomal amphotericin B (5mg/kg/day for 18 days) was given and he improved again. The CT of the chest still showed a nodule in the rightlower lobe, butwith no pleural effusion ( Figure C- arrow). He is now receiving conventional amphotericin $B(50 \mathrm{mg} /$ day) , twice a week, at the outpatient clinic and remains asymptomatic.

0 paciente, de 39 anos, foi admitido ao hospital com história de febre, cefaléia, náuseas, fotofobia e vômitos de início havia seis dias. A punção lombar revelou a presença do fungo Cryptococcus neoformans. 0 teste de ELISA, 0 western blot e o PCR para 0 HIV resultaram negativos. A história clínica e os exames de laboratório excluíram imunodeficiências subjacentes e outras co-morbidades associadas. A tomografia computadorizada do crânio revelou múltiplos nódulos em gânglios da base com captação de contraste (Figura A- setas). 0 paciente recebeu anfotericina B convencional, na dose de $50 \mathrm{mg} /$ dia e melhorou rapidamente. A tomografia computadorizada do tórax (TC) pôs em evidência a presença de derrame pleural bilateral e um nódulo levemente irregular na periferia do lobo inferior do pulmão direito (Figura B - seta). Dez dias após o início do tratamento surgiu insuficiência renal, flebite, sepse e distúrbios hidroeletrolíticos, e a anfotericina B foi trocada pelo fluconazol. 0 paciente recebeu alta hospitalar 25 dias mais tarde em bom estado geral. Vinte dias depois retornou ao hospital com sintomas semelhantes aos da primeirainternação. Nova punção lombar confirmou a presença de meningite; identificou-se 0 antígeno de Cryptococcus no líquor (1:32). 0 paciente recebeu, então, anfotericina B lipossomal ( $5 \mathrm{mg} / \mathrm{kg} / \mathrm{dia}$ ) por 18 dias e apresentou melhora dos sintomas. A segunda TC do tórax confirmou o nódulo na base do pulmão direito, sem derrame pleural (Figura C - seta) . Ele encontra-se em uso de anfotericina B convencional ( $50 \mathrm{mg} / \mathrm{dia}$, duas vezes por semana) em ambulatório e permanece assintomático.

\section{REFERENCES}

1. Chen SCA. Cryptococcosis in Australasia and the treatment of cryptococcal and other fungal infections with liposomal amphotericin B. Journal of Antimicrobial Chemotherapy 49 ( suppl S1) : 57-61, 2002.

2. Ramos-Barbosa S, Guazzelli LS, Severo LC. Criptococose mamária manifesta após corticoterapia. Revista da Sociedade Brasileira de Medicina Tropical 37: 65-66, 2004.

3. Sadayuki M, Sakai S, Soeda H, Yabuuchi H, Masuda K, Hiromasa I, Watanabe H, Matsuo Y. Pulmonary cryptococcosis in immunocompetent patients: high resolution computed tomography characteristics. Journal of Clinical Imaging 28: 191-195, 2004. 